\title{
Painéis de partículas requisitos e métodos de ensaio
}

\author{
Maximiliano dos Anjos Azambuja \\ Departamento de Engenharia Civil e Ambiental / UNESP, \\ Professor associado, maximilianoazam@feb.unesp.br
}

\section{RESUMO}

A apresentação visa oferecer a estudantes, pesquisadores e aos demais interessados, informações básicas sobre métodos de ensaios, para incentivar o aumento da produção tecnológica e de inovação em painéis de partículas. Aborda a classificação dos tipos de painéis de partículas de média densidade e os requisitos gerais de acordo com as condições de utilização, assim como, os métodos de ensaios para avaliação de painéis não estruturais e painéis estruturais, com ênfase na NBR 14810 Painéis de partículas de média densidade - Parte 2: Requisitos e métodos de ensaio, que prescreve os critérios de avaliação das propriedades físicas e mecânicas.

Palavras-chave: métodos de ensaio, requisitos, painel de partículas.

\begin{abstract}
The presentation aims to offer students, researchers and other interested parties, basic information about test methods, to encourage an increase in technological production and innovation in particle boards. It addresses the classification of the types of medium density particle boards and the general requirements according to the conditions of use, as well as the test methods for the evaluation of non-structural panels and structural panels, with emphasis on NBR 14810 Particle boards of medium density - Part 2: Requirements and test methods, which prescribes the criteria for assessing physical and mechanical properties.
\end{abstract}

Keywords: test methods, requirements, particle board. 